\title{
Meningkatkan Prestasi Dan Motivasi Belajar Ipa Dengan Menerapkan Metode Inkuiri Pada Siswa Kelas VI SDN Bile Penanggak Kecamatan Janapria Kabupaten Lombok Tengah Tahun Pelajaran 2017/2018
}

\author{
Sugiarto \\ Guru SDN Bile Penanggak Kec. Janapria Kabupaten Lombok Tengah
}

\begin{abstract}
Abstrak. Untuk bisa mempelajari sesuatu dengan baik, kita perlu mendengar, melihat, mengajukan pertanyaan tentangnya, dan membahasnya dengan orang lain. Bukan hanya itu, siswa perlu "mengerjakannya", yakni menggambarkan sesuatu dengan cara mereka sendiri, menunjukkan contohnya, mencoba mempraktekkan keterampilan dan mengerjakan tugas yang menuntut pengetahuan yang telah mereka dapatkan. Permasalahan yang ingin dikaji dalam penelitian ini adalah: (a) Bagaimanakah peningkatan prestasi belajar siswa dengan diterapkannya metode inkuiri? (b) Bagaimanakah pengaruh metode inkuiri terhadap motivasi belajar siswa? Sedangkan tujuan dari penelitian ini adalah: (a) Untuk meningkatkan pemahaman dan penguasaan mata pelajaran IPA setelah diterapkannya metode inkuiri. (b) Untuk mengetahui pengaruh motivasi belajar siswa setelah diterapkan metode inkuiri. Penelitian ini menggunakan penelitian tindakan (action research) sebanyak tiga siklus. Setiap siklus terdiri dari empat tahap yaitu: perencanaan, kegiatan dan pengamatan, refleksi, dan revisi. Sasaran penelitian ini adalah siswa kelas VI SDN Bile Penanggak. Data yang diperoleh berupa hasil tes formatif, lembar observasi kegiatan belajar mengajar. Dari hasil analisis didapatkan bahwa prestasi belajar siswa mengalami peningkatan dari siklus I sampai siklus III yaitu, siklus I (62,50\%), siklus II (75,00\%), siklus III (87,50\%). Simpulan dari penelitian ini adalah metode inkuiri dapat meningkatkan prestasi dan motivasi belajar IPA siswa kelas VI SDN Bile Penanggak, serta metode ini dapat digunakan sebagai salah satu alternatif pembelajaran IPA.
\end{abstract}

Kata Kunci: Belajar IPA, Metode Inkuiri

\section{PENDAHULUAN \\ Latar Belakang}

Salah satu permasalahan yang dihadapi oleh bangsa Indonesia adalah rendahnya mutu pendidikan, khususnya pendidikan dasar dan menengah. Berbagai usaha telah dilakukan untuk menigkatkan mutu pendidikan nasional, antara lain melalui berbagai pelatihan dan peningkatan kualitas guru, penyempurnaan kurikulum, pengadaan buku dan alat pelajaran, perbaikan sarana dan prasarana pendidikan, dan peningkatan mutu manajemen sekolah. Namun demikian, berbagai indikator mutu pendidikan belum menunjukkan peningkatan yang memadai.Mengajar bukan semata persoalan menceritakan. Belajar bukanlah konsekuensi otomatis dari perenungan informasi ke dalam benak siswa. Belajar memerlukan keterlibatan mental dan kerja siswa sendiri. Penjelasan dan pemeragaan semata tidak akan membuahkan hasil belajar yang langgeng. Yang bisa membuahkan hasil belajar yang langgeng hanyalah kegiatan pengajaran berbasis inkuiri.

Apa yang menjadikan pengajaran menjadi aktif? Agar belajar menjadi aktif siswa harus mengerjakan banyak sekali tugas. Mereka harus menggunakan otak, mengkaji gagasan, memecahkan masalah, dan menerapkan apa yang mereka pelajari. Pengajaran berbasis inkuiri harus gesit, menyenangkan, bersemangat dan penuh gairah. Siswa bahkan sering meninggalkan tempat duduk mereka, bergerak leluasa dan berfikir keras (moving about dan thinking aloud)

Untuk bisa mempelajari sesuatu dengan baik, kita perlu mendengar, melihat, mengajukan pertanyaan tentangnya, dan membahasnya dengan orang lain. Bukan hanya itu, siswa perlu "mengerjakannya", yakni menggambarkan sesuatu dengan cara 
mereka sendiri, menunjukkan contohnya, mencoba mempraktekkan keterampilan, dan mengerjakan tugas yang menuntut pengetahuan yang telah atau harus mereka dapatkan.

Demikian juga halnya dengan siswasiswa di SDN Bile Penanggak khususnya siswa kelas VI Tahun Pelajaran 2017/2018 muatan pembelajaran Ilmu Pengetahuan Alam (IPA). Sebanyak 75\% dari 24 siswa nilai tes formatif yang diperoleh pada tema 2 . Persatuan dalam perbedaan sub tema 3 . Bersatu kita teguh masih di bawah 70 (KKM mata pelajaran IPA). Kenyataan ini membutuhkan solusi pemecahan masalah agar penguasaan siswa sebagian besar berada di atas KKM.

Berdasarkan uraian tersebut di atas penulis mencoba menerapkan salah satu metode pembelajaran, yaitu metode inkuiri untuk mengungkapkan apakah dengan metode ini dapat meningkatkan motivasi dan prestasi belajar IPA siswa. Dalam metode inkuiri siswa lebih aktif dalam memecahkan untuk menemukan, sedang guru berperan sebagai pembimbing atau memberikan petunjuk cara memecahkan masalah itu.

Dengan menyadari gejala-gejala atau kenyataan tersebut di atas, maka dalam penelitian ini penulis mengambil judul "Meningkatkan Prestasi dan Motivasi Belajar IPA dengan Metode Inkuiri pada Siswa Kelas VI SDN Bile Penanggak Tahun Pelajaran 2017/2018".

\section{Rumusan Masalah}

Bertitik tolak dari latar belakang di atas, penulis merumuskan permasalahannya sebagai berikut: (1) Bagaimanakah peningkatan prestasi belajar siswa dengan diterapkannya metode inkuiri pada siswa Kelas VI SDN Bile Penanggak Tahun Pelajaran 2017/2018?, (2) Bagaimanakah pengaruh metode inkuiri terhadap motivasi belajar siswa Kelas VI SDN Bile Penanggak Tahun Pelajaran 2017/2018?

\section{Tujuan Penelitian}

Sesuai dengan permasalahan di atas, penelitian ini bertujuan untuk: (1) Mengetahui seberapa jauh pemahaman dan penguasaan muatan pelajaran IPA setelah diterapkannya metode inkuiri pada siswa
Kelas VI SDN Bile Penanggak Tahun Pelajaran 2017/2018, (2) Mengetahui pengaruh motivasi belajar siswa dalam membangun ingatannya terhadap materi pelajaran IPA setelah diterapkan metode inkuiri pada siswa Kelas VI SDN Bile Penanggak Tahun Pelajaran 2017/2018.

\section{Manfaat Penelitian}

1. Bagi Siswa

Tindakan yang diberikan dalam dua siklus dapat bermanfaat bagi siswa untuk memberikan latihan/pengalaman untuk menyelesaikan masalah dan meningkatkan prestasi belajar siswa.

2. Bagi Guru

Hasil PTK dapat bermanfaat bagi guru lain yang memiliki masalah yang sama/serupa sebagai input atau msukan untuk melakukan pemecahan masalah kelas di sekolah lain dalam rangka meningkatkan kualitas proses dan hasil pembelajaran IPS dengan menggunakan model pembelajaran Cooperative Learning.

3. Bagi Sekolah

Hasil PTK ini dapat digunakan sebagai masukan atau informasi untuk meningkatkan kualitas proses atau hasil pembelajaran dikelas dengan menghimbau kepada guru untuk melakukan PTK.

\section{LANDASAN TEORI DAN KAJIAN PUSTAKA}

Prestasi Belajar

Sebelum dijelaskan pengertian mengenai prestasi belajar, terlebih dahulu akan dikemukakan tentang pengertian prestasi. Prestasi adalah hasil yang telah dicapai. Dengan demikian bahwa prestasi merupakan hasil yang telah dicapai oleh seseorang setelah melakukan sesuatu pekerjaan/aktivitas tertentu.

Jadi prestasi belajar adalah hasil yang telah dicapai setelah belajar. Oleh karena itu semua individu dengan adanya belajar hasilnya dapat dicapai. Setiap individu belajar menginginkan hasil yang sebaik mungkin. Oleh karena itu setiap individu harus belajar dengan sebaik-baiknya supaya prestasinya berhasil dengan baik. 


\section{Faktor-Faktor Yang Memengaruhi Prestasi Belajar}

Faktor-faktor yang memengaruhi prestasi belajar dapat dibedakan menjadi dua golongan yaitu:

1. Faktor yang ada pada diri siswa itu sendiri yang disebut faktor individu. Yang termasuk ke dalam faktor individu antara lain adalah faktor kematangan atau pertumbuhan, kecerdasan, latihan, motivasi, dan faktor pribadi.

2. Faktor yang ada di luar individu yang disebut dengan faktor sosial. Yang termasuk faktor sosial antara lain adalah faktor keluarga, keadaan rumah tangga, guru dan cara mengajarnya, lingkungan dan kesempatan yang ada atau tersedia, dan motivasi sosial.

Berdasarkan faktor yang memengaruhi kegiatan belajar di atas menunjukkan bahwa belajar itu merupakan proses yang cukup kompleks. Artinya pelaksanaan dan hasilnya sangat ditentukan oleh faktor-faktor di atas. Bagi siswa yang berada dalam faktor yang mendukung kegiatan belajar akan dapat dilalui dengan lancar dan pada gilirannya akan memperoleh prestasi atau hasil belajar yang baik.

Sebaliknya bagi siswa yang berada dalam kondisi belajar yang tidak menguntungkan, dalam arti tidak ditunjang atau didukung oleh faktor-faktor di atas, maka kegiatan atau proses belajarnya akan terhambat atau menemui kesulitan.

\section{Metode Inkuiri}

Pembelajaran dengan penemuan (inquiry) merupakan satu komponen penting dalam pendekatan konstruktivistik yang telah memiliki sejarah panjang dalam inovasi atau pembaharuan pendidikan. Dalam pembelajaran dengan metode penemuan/inkuiri, siswa didorong untuk memiliki pengalaman dan melakukan percobaan yang memungkinkan mereka menemukan prinsip-prinsip untuk diri mereka sendiri, Bruner (1966), penganjur pembelajaran dengan metode inkuiri menyatakan sebagai berikut: "Kita mengajarkan suatu bahan kajian tidak untuk menghasilkan perpustakaan hidup tentang bahan kajian itu, tetapi lebih ditujukan untuk membuat siswa berpikir untuk diri mereka sendiri, meneladani seperti apa yang dilakukan oleh seorang sejarawan, mereka turut mengambil bagian dalam proses, bukan suatu produk (Nur \& Wikandari, 2000:10). Belajar dengan penemuan dapat diterapkan dalam banyak mata pelajaran. Sebagai contoh, siswa diberi sederet silinder dengan ukuran dan berat yang berbeda-beda. Siswa diminta untuk menggelindingkan silinder tersebut pada suatu bidang miring. Bila percobaan itu dilakukan dengan benar, siswa akan dapat menemukan prinsip-prinsip utama yang menentuan kecepatan silinder tersebut.

\section{Keuntungan Metode Inkuiri;}

Belajar dengan penemuan mempunyai beberapa keuntungan. Pembelajaran dengan metode inkuiri memacu keinginan siswa untuk mengetahui, memotivasi mereka untuk melanjutkan pekerjaannya hingga mereka menemukan jawabannya. Siswa juga belajar memecahkan masalah secara mandiri dan memiliki keterampilan berpikir kritis karena mereka harus selalu menganalisis dan menangani informasi.

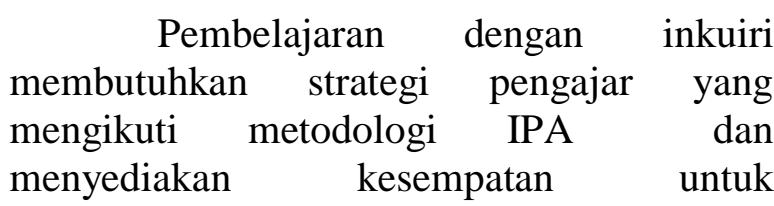
pembelajaran bermakna.Inkuiri adalah seni dan ilmu bertanya dan menjawab. Inkuiri melibatkan observasi dan pengukuran, pembuatan hipotesis dan interpretasi, pembentukan model dan pengujian model. Inkuiri menuntut adanya eksperimentasi, refleksi, dan pengenalan akan keunggulan dan kelamahan metode-metodenya sendiri.

Selama proses inkuiri berlangsung, seorang guru dapat mengajukan suatu pertanyaan atau mendorong siswa untuk mengajukan pertanyaan-pertanyaan mereka sendiri. Pertanyaannya bersifat open-ended, memberi kesempatan kepada siswa untuk menyelidiki sendiri dan mereka mencari jawaban sendiri (tetapi tidak hanya satu jawaban yang benar).

Inkuiri adalah apa yang dibuat oleh para ilmuwan. Para ilmuwan melakukan inkuiri dengan suatu cara formal dan sistematis, dan dalam proses melakukan 
inkuiri para ilmuwan memberikan kontribusi pada tubuh informasi yang bersifat kolektif yang disebut pengetahuan. Dalam proses mengalami ilmu melalui inkuiri, siswa belajar bagaimana menjadi ilmuwan. Mereka belajar lebih banyak lagi dibanding hanya konsep dan fakta, mereka mempelajari berbagai proses yang terlibat dalam pemantapan konsep dan fakta.

Inkuiri memberikan kepada siswa pengalaman-pengalaman belajar yang nyata dan aktif. Siswa diharapkan mengambil inisiatif. Mereka dilatih bagaimana memecahkan masalah, membuat keputusan, dan memperoleh keterampilan. Inkuiri memungkinkan siswa dalam berbagai tahap perkembangannya bekerja dengan masalahmasalah yang sama dan bahkan mereka bekerja sama mencari solusi terhadap masalah-masalah. Setiap siswa harus memainkan dan memfungsikan talentanya masing-masing.

Inkuiri memungkinkan terjadinya integrasi berbagai disiplin ilmu. Ketika siswa melakukan eksplorasi mereka cenderung mengajukan pertanyaan-pertanyaan yang akan melibatkan IPA dan matematika, ilmu sosial, bahasa, seni, dan teknik.

Inkuiri melibatkan pula komunikasi.

Siswa harus mengajukan pertanyaanpertanyaan yang berarti dan berhubungan. Mereka harus melaporkan hasil-hasil temuannya, lisan atau tertulis. Dengan begitu, mereka bekerja dan mengajar satu sama lain. Inkuiri memungkinkan guru mempelajari siswa-siswanya; Siapa mereka?, Apa yang mereka ketahui?, dan Bagaimana mereka bekerja?. Pemahaman guru tentang siswa akan memungkinkan guru untuk menjadi fasilitator yang lebih efektif dalam proses pencarian ilmu oleh siswa.

Ketika guru menggunakan teknik inkuiri, guru tidak boleh banyak bertanya atau berbicara. Terlalu banyak intervensi, terlalu banyak bertanya, dan terlalu banyak menjawab akan mengurangi proses belajar siswa melalui inkuiri. Dengan demikian, proses belajar tidak akan lagi menyenangkan. Dalam proses inkuiri, siswa dituntut untuk bertanggung jawab bagi pendidikan mereka sendiri. Guru yang menaruh perhatian pada pribadi siswa, akan menemukan kegiatankegiatan yang disukai siswa, juga hal-hal yang baik yang ada dalam diri siswanya, dan kesulitian-kesulitan yang mengganggu siswa dalam proses belajar. Guru dituntut menyesuaikan diri terhadap gaya belajara siswanya.

Siklus inkuiri adalah: (1) Observasi (Observation); (2) Bertanya (Questioning); (3) Mengajukan dugaan (Hipothesis); (4) Pengumpulan data (Data Gathering); dan Penyimpulan (Conclusion).

Inkuiri adalah satu proses yang bergerak dari langkah observasi sampai langkah pemahaman. Inkuiri dimulai dengan observasi yang menjadi dasar pemunculan berbagai pertanyaan yang diajukan siswa. Jawaban terhadap pertanyaan-pertanyaan tersebut dikejar dan diperoleh melalui suatu siklus pembuatan prediksi, perumusan hipotesis, pengembangan cara-cara pengujian hipotesis, pembuatan observasi lanjutan, penciptaan teori dan model-model konsep yang didasarkan pada data dan pengetahuan. Inkuiri menciptakan berbagai kesempatan bagi guru untuk mempelajari bagaimana otak siswa bekerja. Guru dapat memanfaatkannya untuk menentukan situasi-situasi belajar yang tepat dan memfasilitasi siswa dalam proses pencarian ilmu.

Dalam proses inkuiri, siswa belajar dan dilatih bagaimana mereka harus berpikir kritis. Berpikir kritis merupakan salah satu tujuan pendidikan. Ketika siswa belajar berpikir kritis, mereka akan memperlihatkan pikiran-pikiran dan proses-proses sebagai berikut: (1) Mengajukan pertanyaan seperti "Bagaimana itu kita tahu?" atau "Apa buktinya?" (2) Mengetahui perbedaan antara observasi dan kesimpulan, (3) Mengetahui bahwa semua gagasan ilmiah itu dapat berubah dan bahwa teori yang ada adalah teori-teori yang terbaik berdasarkan bukti yang kita miliki sejauh ini, (4) Mengetahui bahwa diperlukan bukti yang cukup untuk menarik suatu kesimpulan yang kuat, (5) Memberi penjelasan atau interpretasi, melakukan observasi dan/atau prediksi, (6) Selalu mencari konsistensi terhadap kesimpulan-kesimpulan yang diambil dan 
memberikan penjelasan dengan rasa percaya diri.

\section{METODE PENELITIAN}

\section{Tempat, Waktu, dan Subyek Penelitian}

Tempat penelitian adalah tempat yang digunakan dalam melakukan penelitian untuk memperoleh data yang diinginkan. Penelitian ini bertempat di SDN Bile Penanggak tahun pelajaran 2017/2018, pada siswa kelas VI Rancangan Penelitian

$$
\text { Penelitian ini menggunakan }
$$

Penelitian Tindakan Kelas (PTK). Menurut Tim Pelatih Proyek PGSM, PTK adalah suatu bentuk kajian yang bersifat reflektif oleh pelaku tindakan yang dilakukan untuk meningkatkan kemantapan rasional dari tindakan mereka dalam melaksanakan tugas, memperdalam pemahaman terhadap tindakan-tindakan yang dilakukan itu, serta memperbaiki kondisi dimana praktek pembelajaran tersebut dilakukan (dalam Mukhlis, 2000: 3).

Sedangkan menurut Mukhlis (2000: 5) PTK adalah suatu bentuk kajian yang bersifat sistematis reflektif oleh pelaku tindakan untuk memperbaiki kondisi pembelajaran yang dilakukan.

Adapun tujuan utama dari PTK adalah untuk memperbaiki/meningkatkan praktek pembelajaran secara berkesinambungan, sedangkan tujuan penyertaannya adalah menumbuhkan budaya meneliti di kalangan guru (Mukhlis, 2000: 5).

Sesuai dengan jenis penelitian yang dipilih, yaitu penelitian tindakan, maka penelitian ini menggunakan model penelitian tindakan dari Kemmis dan Taggart (dalam Sugiarti, 1997: 6), yaitu berbentuk spiral dari siklus yang satu ke siklus yang berikutnya. Setiap siklus meliputi planning (rencana), action (tindakan), observation (pengamatan), dan reflection (refleksi). Langkah pada siklus berikutnya adalah perencanaan yang sudah direvisi, tindakan, pengamatan, dan refleksi. Sebelum masuk pada siklus 1 dilakukan tindakan pendahuluan yang berupa identifikasi permasalahan. Siklus spiral dari tahap-tahap penelitian tindakan kelas dapat dilihat pada gambar berikut:

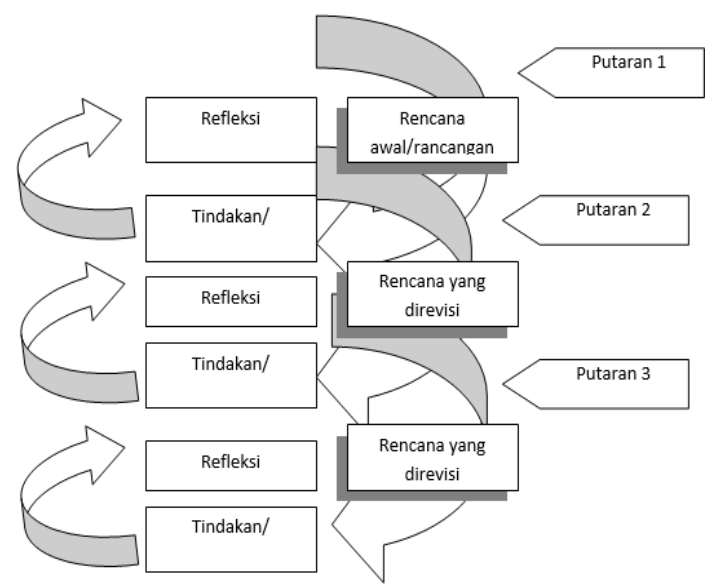

Gambar 3.1 Alur PTK

Instrumen Penelitian

Instrumen yang digunakan dalam penelitian ini terdiri dari: Silabus, Rencana Pelaksanaan Pembelajaran (RPP), Tes formatif

\section{Metode Pengumpulan Data}

Data-data yang diperlukan dalam penelitian ini diperoleh melalui observasi pembelajaran dengan metode inkuiri dan tes formatif.

\section{Teknik Analisis Data}

Untuk mengetahui keefektifan suatu metode dalam kegiatan pembelajaran perlu diadakan analisis data. Pada penelitian ini menggunakan teknik analisis deskriptif kualitatif, yaitu suatu metode penelitian yang bersifat menggambarkan kenyataan atau fakta sesuai dengan data yang diperoleh dengan tujuan untuk mengetahui prestasi belajar yang dicapai siswa juga untuk memperoleh respon siswa terhadap kegiatan pembelajaran serta aktivitas siswa selama proses pembelajaran. Untuk menganalisis tingkat keberhasilan atau persentase keberhasilan siswa setelah proses belajar mengajar setiap putarannya dilakukan dengan cara memberikan evaluasi berupa soal tes tertulis pada setiap akhir putaran. Analisis ini dihitung dengan menggunakan statistik sederhana yaitu:

Untuk menilai ulangan atau tes formatif peneliti melakukan penjumlahan nilai yang diperoleh siswa, yang selanjutnya dibagi dengan jumlah siswa yang ada di kelas tersebut sehingga diperoleh rata-rata tes formatif dapat dirumuskan: 


$$
\bar{X}=\frac{\sum X}{\sum N}
$$

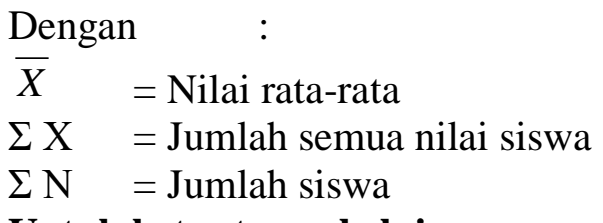

\section{Untuk ketuntasan belajar}

Ada dua kategori ketuntasan belajar yaitu secara perorangan dan secara klasikal. Berdasarkan petunjuk pelaksanaan belajar mengajar kurikulum 2013 (Permendikbud, 2014), yaitu seorang siswa telah tuntas belajar bila telah mencapai Ketuntasan Belajar Minimal (KBM) yang ditetapkan guru dan kelas disebut tuntas belajar bila di kelas tersebut terdapat $85 \%$ yang telah mencapai KBM. Untuk menghitung persentase ketuntasan belajar digunakan rumus sebagai berikut:$$
P=\frac{\sum \text { Siswa.yang.tuntas.belajar }}{\sum \text { Siswa }} \times 100 \%
$$$$
\text { HASIL PENELITIAN DAN }
$$$$
\text { PEMBAHASAN }
$$

Siklus I

$$
\begin{aligned}
& \text { Pelaksanaan kegiatan belajar } \\
& \text { mengajar untuk siklus I dilaksanakan pada } \\
& \text { tanggal 07 September } 2017 \text { di Kelas VI } \\
& \text { dengan jumlah siswa } 24 \text { siswa. Dalam hal ini } \\
& \text { peneliti bertindak sebagai guru. Adapun } \\
& \text { proses belajar mengajar mengacu pada } \\
& \text { rencana pelajaran yang telah dipersiapkan. } \\
& \text { Pengamatan (observasi) dilaksanakan } \\
& \text { bersamaan dengan pelaksaaan belajar } \\
& \text { mengajar. }
\end{aligned}
$$

Pada akhir proses belajar mengajar siswa diberi tes formatif I dengan tujuan untuk mengetahui tingkat keberhasilan siswa dalam proses belajar mengajar yang telah dilakukan. Berdasarkan hasil nalisa data dapat dijelaskan bahwa dengan menerapkan metode inkuiri diperoleh nilai rata-rata prestasi belajar siswa adalah 66,67 dan ketuntasan belajar mencapai $62,50 \%$ atau ada 15 siswa dari 24 siswa sudah tuntas belajar. Hasil tersebut menunjukkan bahwa pada siklus pertama secara klasikal siswa belum tuntas belajar, karena siswa yang memperoleh nilai $\geq 65$ hanya sebesar $62,50 \%$ lebih kecil dari persentase ketuntasan yang dikehendaki yaitu sebesar 85\%. Hal ini disebabkan karena guru belum mampu membimbing siswa merumuskan masalah, menemukan konsep, dan memberikan umpan balik yang sesuai, sedangkan siswa belum mampu bekerja dalam kelompok, mengajukan/menanggapi ide/pertanyaan, dan merangkum pembelajaran

\section{Refleksi}

Pada tahap ini akan dikaji apa yang telah terlaksana dengan baik maupun yang masih kurang baik dalam proses belajar mengajar dengan penerapan metode inkuiri. Dari data-data yang telah diperoleh dapat diuraikan sebagai berikut:

Selama proses belajar mengajar guru belum mampu melaksanakan semua pembelajaran dengan baik. Hal ini ditunjukkan dengan kelemahan guru dalam membimbing siswa merumuskan masalah, menemukan konsep, dan memberikan umpan balik yang sesuai dengan hasil evaluasi pembelajaran. Namun demikian, guru telah mampu membangun suasana kelas yang aktif dan menjelaskan materi-materi yang masih awam bagi siswa.

Sementara itu siswa sudah mulai bergairah dan termotivasi untuk belajar, tetapi siswa belum mampu bekerja dalam kelompok, mengajukan/menanggapi ide/pertanyaan, dan merangkum pembelajaran dengan cepat dan tepat.

\section{Siklus II}

Pelaksanaan kegiatan belajar mengajar untuk siklus II dilaksanakan pada tanggal 12 September 2017 di Kelas VI dengan jumlah siswa 24 siswa. Dalam hal ini peneliti bertindak sebagai guru. Adapun proses belajar mengajar mengacu pada rencana pelajaran dengan memperhatikan revisi pada siklus I, sehingga kesalahan atau kekurangan pada siklus I tidak terulang lagi pada siklus II. Pengamatan (observasi) dilaksanakan bersamaan dengan pelaksanaan belajar mengajar.

Pada akhir proses belajar mengajar siswa diberi tes formatif II dengan tujuan untuk mengetahui tingkat keberhasilan siswa dalam proses belajar mengajar yang telah dilakukan. Instrumen yang digunakan adalah 
tes formatif II. Adapun data hasil penelitian pada siklus II adalah sebagai berikut:

Selama proses belajar mengajar guru sudah mampu memperbaiki kelemahan pada siklus I secara bertahap. Hal ini ditunjukkan dengan kemampuan guru dalam membimbing siswa merumuskan masalah dan menemukan konsep, tetapi guru masih belum malsimal dalam memberikan umpan balik yang sesuai dengan hasil evaluasi pembelajaran.

Sementara itu siswa sudah menunjukkan kemampuannya bekerja dalam kelompok dan merangkum pembelajaran dengan cepat dan tepat, tetapi masih kurang dalam menyampaikan ide atau menanggapi suatu permasalahan dengan kemampuan berpikirnya.

\section{Pembahasan}

\section{Ketuntasan Hasil belajar Siswa}

Melalui hasil peneilitian ini menunjukkan bahwa penerapan metode inkuiri memiliki dampak positif dalam meningkatkan prestasi belajar siswa. Hal ini dapat dilihat dari semakin mantapnya pemahaman dan penguasaan siswa terhadap materi yang telah disampaikan guru selama ini (ketuntasan belajar meningkat dari sklus I, II, yaitu masing-masing 62,50\%, 75,00\%, . Pada siklus ketuntasan belajar siswa secara klasikal telah tercapai.

\section{Kemampuan Guru dalam Mengelola Pembelajaran}

Berdasarkan analisis data, diperoleh aktivitas siswa dalam proses pembelajaran menggunakan metode inkuiri dalam setiap siklus mengalami peningkatan. Hal ini berdampak positif terhadap proses mengingat kembali materi pelajaran yang telah diterima selama ini, yaitu dapat ditunjukkan dengan meningkatnya nilai rata-rata siswa pada setiap siklus yang terus mengalami peningkatan.

\section{Aktivitas Guru dan Siswa dalam Pembelajaran}

Berdasarkan analisis data, diperoleh aktivitas siswa dalam proses pembelajaran IPA dengan menggunakan metode inkuiri yang paling dominan adalah bekerja dengan menggunakan alat/media, mendengarkan/ memperhatikan penjelasan guru, dan diskusi antar siswa/antara siswa dengan guru. Jadi dapat dikatakan bahwa aktivitas siswa dapat dikategorikan aktif.

Sedangkan untuk aktivitas guru selama pembelajaran telah melaksanakan langkah-langkah pembelajaran menggunakan metode inkuiri dengan baik. Hal ini terlihat dari aktivitas guru yang muncul di antaranya aktivitas membimbing dan mengamati siswa dalam mengerjakan kegiatan, menjelaskan/melatih menggunakan alat, memberi umpan balik/evaluasi/tanya jawab dimana persentase untuk aktivitas di atas cukup besar.

\section{KESIMPULAN DAN SARAN}

Dari hasil kegiatan pembelajaran yang telah dilakukan selama tiga siklus dan berdasarkan seluruh pembahasan serta analisis yang telah dilakukan dapat disimpulkan sebagai berikut:

Pembelajaran dengan metode inkuiri memiliki dampak positif dalam meningkatkan prestasi belajar siswa yang ditandai dengan peningkatan ketuntasan belajar siswa dalam setiap siklus, yaitu siklus I $(62,50 \%)$, siklus II $(75,00 \%)$.

Penerapan metode inkuiri mempunyai pengaruh positif, yaitu dapat meningkatkan motivasi belajar siswa untuk mempelajari pelajaran IPA yang ditunjukan dengan ratarata jawaban siswa yang menyatakan bahwa siswa tertarik dan berminat dengan pembelajaran menggunakan metode inkuiri sehingga mereka menjadi termotivasi untuk belajar.

\section{DAFTAR PUSTAKA}

Arikunto, Suharsimi. 1997. Dasar-dasar Evaluasi Pendidikan. Jakarta: Bumi Aksara.

Berg, Euwe Vd. (1991). Miskonsepsi IPA dan Remidi Salatiga: Universitas Kristen Satya Wacana.

Hamalik, Oemar. 2002. Psikologi Belajar dan Mengajar. Bandung: Sinar Baru Algesindo.

Joyce, Bruce dan Weil, Marsh. 1972. Models of Teaching Model. Boston: A Liyn dan Bacon.

Masriyah. 1999. Analisis Butir Tes. Surabaya: Universitas Press.

Mukhlis, Abdul. (Ed). 2000. Penelitian Tindakan Kelas. Makalah Panitia 
Pelatihan Penulisan Karya Ilmiah untuk Guru-guru se-Kabupaten Tuban.

Nur, Moh. 2001. Pemotivasian Siswa untuk Belajar. Surabaya. University Press. Universitas Negeri Surabaya.

Soedjadi, dkk. 2000. Pedoman Penulisan dan Ujian Skripsi. Surabaya; Unesa Universitas Press.

Suryosubroto, B. 1997. Proses Belajar Mengajar di Sekolah. Jakarta: PT. Rineksa Cipta.

Usman, Uzer. 2000. Menjadi Guru Profesional. Bandung: PT. Remaja Rosdakarya.

Widoko. 2002. Metode Pembelajaran Konsep. Surabaya: Universitas Negeri Surabaya. 